\title{
Varietal evaluation of postharvest behavior in apricot fruits
}

\author{
J.A. Salazar, P. Martínez-Gómez and D. Ruiz \\ Departamento de Mejora Vegetal, CEBAS-CSIC, Espinardo, Murcia, Spain
}

\section{Summary}

Background of the study - In order to increase exportation in a worldwide context and maintain optimum fruit quality for consumers, we must pay special attention to postharvest behavior and shelf-life during the process of fruit storage and transportation. Apricot (Prunus armeniaca L.) fruits are characterized by a short market life compared to other temperate fruit species such as peaches or plums. For this reason, a long shelf-life is an important new objective in apricot breeding programs. Objective - The aim of this work was to evaluate the postharvest behavior and shelf-life period in different apricot varieties. Methods - Sixteen varieties from the CEBAS-CSIC breeding program were subjected to different postharvest treatments, combining cold storage periods at $1^{\circ} \mathrm{C}$ and standard room temperature conditions at $20^{\circ} \mathrm{C}$ to simulate the usual marketing channels. Fruit weight loss, skin and flesh colour, firmness, soluble solids content, malic acid content and the soluble solids-titratable acidity ratio were monitored for each variety. Additionally, the visual appearance, fruit texture and flavor were determined as the main sensorial traits. Results - Significant differences among varieties were observed, indicating that postharvest behavior is genotype-dependent. These results made it possible to identify several apricot varieties with a long shelf-life period of up to 35 days: 'Deseo', 'Dorada', 'Maravilla', 'Murciana' and 'Rosa'. Conclusion - Among the varieties studied, 'Deseo', 'Dorada', 'Maravilla', 'Murciana' and 'Rosa' are the most suitable for prolonged storage and long-distance export. These characteristics determine the commercial interest of these apricot varieties together with their potential use as progenitors in breeding programs.

Keywords

cold storage, fruit quality, postharvest, Prunus armeniaca, ripening, shelf-life

\section{Introduction}

According to botanical classification, apricots (Prunus armeniaca L.) belong to the Rosaceae family and are classified within the subfamily Prunoideae and the subgenus Prunus of the genus Prunus. Apricot fruits have an exterior fleshy part (exocarp and mesocarp) that surrounds a hard stone (endocarp) with a seed inside. One of the great advantages of consuming fresh apricots is their nutritional value - they are rich in nutritional compounds (Ali et al., 2015). Apricots are a great source of fiber, minerals $(\mathrm{K}, \mathrm{Ca}, \mathrm{Fe}, \mathrm{Mg}, \mathrm{Zn}, \mathrm{P}$ and $\mathrm{Se}$ ) and vitamins (A, C, thiamine, riboflavin, niacin and pantothenic acid). In addition, the apricot is well known for its high

\section{Significance of this study}

What is already known on this subject?

- Apricot is characterized by its extremely short shelflife period, being necessary to develop new varieties and techniques in order to improve its postharvest behavior.

What are the new findings?

- In this work, the postharvest behavior of apricot varieties has been evaluated, offering a wide range of possibilities depending on growers and breeders' preferences.

What is the expected impact on horticulture?

- Some of these varieties could be incorporated into current genetic breeding programs in order to increase the apricot post-harvest life.

carotenoid content (Ruiz et al., 2005; Fratianni et al., 2018). From the point of view of consumer acceptance, size, colour, flavor, aroma and firmness are among the most important pomological characteristics related to fruit quality along with sugars, organic acids and volatile compounds (Souty et al., 1991; Baldwin, 2002; Infante et al., 2006, 2008a; Ruiz and Egea, 2008).

In postharvest physiology, we consider a fruit to be "mature" at "that stage at which a commodity has reached a sufficient development level after harvesting and postharvest handling, its quality will be at least the minimum acceptable to the ultimate consumer" (Reid, 1992). Apricots are characterized by a limited postharvest life and remain fresh only for $1-4$ weeks when stored at $-0.5^{\circ} \mathrm{C}$ to $1^{\circ} \mathrm{C}$ and $90 \pm 5 \%$ relative humidity (Fan et al., 2000; Crisosto and Kader, 2016). Firmness, attractiveness and taste are the principal parameters affecting apricot fruit quality during the conservation process (Gurrieri et al., 2001). Recent studies have reported that storage at lower temperatures (less than $0^{\circ} \mathrm{C}$ ) could extend the storage period (Fan et al., 2018a; Stanley et al., 2013). However, Infante et al. (2008b) found that apricot shelf-life after storage at $0^{\circ} \mathrm{C}$ was shortened and fruit quality deteriorated rapidly.

Apricot fruits are climacteric and have a short shelf-life period and rapid senescence, including flesh softening and loss of overall flavor, which supposes the main limitation for storage. An increase in the respiration ratio and ethylene production is the main factor triggering the fruit ripening process and senescence. In addition to flesh softening and flavor loss, we have to consider two main types of physiological disorders that also reduce apricot storage potential: internal browning and internal breakdown (Manolopoulou and Mallidis, 1999). Ethylene inhibitors such as 1-methylcyclopropene (1-MCP) are commercially applied to some climacteric fruits to delay the natural fruit senescence pro- 
cess (Salazar et al., 2019). Some studies have confirmed that 1-MCP application not only slows fruit softening, but also produces less internal browning and gel breakdown compared to untreated fruit (Lurie and Weksler, 2005).

Generally, to obtain the best flavor and aroma, apricots should be harvested at their optimum eating ripeness when they reach their full color potential, ensuring greater sensory acceptability. But if the objective is to commercialize them, apricot fruits require long-term cold storage and should be harvested at pre-climacteric stage, i.e., before they reach their characteristic flavor and colour (Aubert and Chanforan, 2007). Hence, commercial apricot fruits are often harvested unripe and still firm, stored at low temperatures for some time and then transported to market (Xi et al., 2016). This long process affects their eating quality and often results in fruits with an unpleasant taste and aroma (Manolopoulou and Mallidis, 1999; Dong et al., 2002).

In this context, it is necessary to combine efficient storage protocols with suitable apricot varieties to minimize the loss of sensorial fruit quality during the harvesting and commercialization process. Some of the most important quality characteristics to be considered are fruit size, shape, and the absence of defects (including gel breakdown and pit burn) and/or decay. In addition, apricots with high soluble solids content ( $>10 \%)$, moderate acidity and good firmness attain high consumer acceptance. Although there are numerous studies on the conservation protocols for apricot fruits, varietal studies linked to shelf-life extension are scarce and lack clear conclusions.

The aim of this work was to evaluate the postharvest behavior of sixteen apricot varieties from the CEBAS-CSIC breeding program (Murcia, Spain) in order to obtain useful information about how shelf-life extension combining different cold storage periods affects fruit quality.

\section{Materials and methods}

\section{Plant material}

Sixteen new apricot varieties from the CEBAS-CSIC breeding program were evaluated (Table 1). All of the vari- eties were cultivated in the same experimental orchard (south-eastern Spain, $37^{\circ} \mathrm{N}$ latitude, $1^{\circ} \mathrm{W}$ longitude, $350 \mathrm{~m}$ altitude) according to habitual apricot orchard management.

\section{Fruit sampling and storage conditions}

Fruit sampling was carried out on three trees per genotype, which had an age of at least 10 years under the same management conditions, ensuring a homogeneous harvest in the same experimental orchard. Fruits were manually harvested at two maturation stages: at optimum eating ripeness and commercial maturity. The fruits at commercial maturity were cold stored for different periods of time, including a control without cold storage (T0). Optimum eating ripeness was determined according to skin colour and firmness (Sims and Comin, 1963; Salazar et al., 2013) when the fruits covered the totality of their skin colour and reached a firmness close to $15 \mathrm{~N}$ while the commercial maturity was determined when the fruits did not cover their skin colour completely and fruit firmness was over $40 \mathrm{~N}$ (Contador et al., 2016) in order to favor a longer shelf-life of the fruit.

Storage treatments combined periods of 15, 25 and 35 days at $1^{\circ} \mathrm{C}$ and $90 \%$ relative humidity and periods of 2 and 3 days at $20^{\circ} \mathrm{C}$ and $70-80 \%$ relative humidity (Table 2). Nine fruits per storage treatment and variety were evaluated (nine replications). These treatments simulated commercial cold storage conditions together with standard room temperature conditions.

\section{Pomological and sensorial trait evaluation}

Eight pomological traits were evaluated: fruit weight, weight loss, firmness, skin colour, flesh colour, soluble solids content, malic acid content and the soluble solids-titratable acidity ratio. Fruit weight was determined using a Blauscal digital scale (model AH-600) with an accuracy of $0.01 \mathrm{~g}$, and weight loss was determined as the average difference between the initial weight and final weight of the fruit set within each treatment. Fruit firmness was evaluated by compression (stress area of $5 \mathrm{~mm}^{2}$ ) using a TA.XT plus texturometer (Texture Technologies Corp., U.S.A.) equipped with a flat plate $(5 \mathrm{~cm})$, obtaining the maximum force $(\mathrm{N})$ required

TABLE 1. Apricot varieties assayed including the pedigree, origin and main agronomic characteristics (self-compatibility, flowering, ripening time and skin colour).

\begin{tabular}{|c|c|c|c|c|c|c|}
\hline Variety & Pedigree & Self-compatibility & $\begin{array}{c}\text { Sharka } \\
\text { resistance }\end{array}$ & Flowering & Ripening & Skin colour \\
\hline 'Deseo' & Orange Red × Tardif de Bordaneil & Self-compatible & No & Late & Medium-late & Orange/Red \\
\hline 'Cebas 57' & Z701-1 × Búlida Precoz & Self-compatible & Yes & Early & Very early & Light orange/Red \\
\hline 'Búlida' & Unknown & Self-compatible & Yes & Medium & Medium & Light orange \\
\hline 'Currot' & Unknown & Self-compatible & Yes & Very early & Very early & Light yellow \\
\hline 'Dorada' & Bergeron × Moniquí & Self-compatible & No & Late & Late & Yellow \\
\hline 'Estrella' & Orange Red × Z211-18 & Self-incompatible & No & Medium & Medium & Orange/Red \\
\hline 'Maravilla' & Orange Red × Z211-18 & Self-incompatible & No & Medium & Medium & Orange/Red \\
\hline 'Mirlo blanco' & Rojo Pasión × Búlida Precoz & Self-compatible & Yes & Early & Very early & Light orange/Red \\
\hline 'Mirlo anaranjado' & Rojo Pasión × Búlida Precoz & Self-compatible & Yes & Early & Very early & Light orange/Red \\
\hline 'Mirlo rojo' & Rojo Pasión × Búlida Precoz & Self-compatible & Yes & Early & Early & Light orange/Red \\
\hline 'Murciana' & Orange Red $\times$ Currot & Self-compatible & Yes & Medium & Medium & Light orange/Red \\
\hline 'Rojo pasión' & Orange Red × Currot & Self-compatible & Yes & Medium & Early & Light orange/Red \\
\hline 'Rosa' & Orange Red × Palsteyn & Self-incompatible & No & Medium & Medium & Orange/Red \\
\hline 'Sublime' & Orange Red × Z211-18 & Self-incompatible & No & Medium & Medium & Orange/Red \\
\hline 'Tardorange' & Orange Red × Tardif de Bordaneil & Self-compatible & Yes & Late & Late & Orange/Red \\
\hline 'Valorange' & Orange Red × Currot & Self-compatible & Yes & Medium & Medium & Orange/Red \\
\hline
\end{tabular}


TABLE 2. Summary of assayed treatments combining cold storage at $1^{\circ} \mathrm{C}$ and relative humidity of $90 \%$ with periods at $20^{\circ} \mathrm{C}$ and relative humidity of $70-80 \%$. These treatments simulated commercial storage conditions together with standard distribution conditions at room temperature.

\begin{tabular}{lcc}
\hline Treatment & $1^{\circ} \mathrm{C} / \mathrm{RH}: 90 \%$ & $20^{\circ} \mathrm{C} / \mathrm{RH}: 70 \%$ \\
\hline Fresh consumption & - & - \\
T0 & - & - \\
T1 & - & 2 days \\
T2 & 0 days & 3 days \\
T3 & 15 days & - \\
T4 & 15 days & 2 days \\
T5 & 15 days & 3 days \\
T6 & 25 days & - \\
T7 & 25 days & 2 days \\
T8 & 25 days & 3 days \\
T9 & 35 days & - \\
T10 & 35 days & 2 days \\
T11 & 35 days & 3 days \\
\hline
\end{tabular}

* Fruits at optimum eating ripeness.

T0 to T11 were harvested at commercial maturity.

for fruit deformation of $5 \mathrm{~mm}$ extension at a speed of 25 mm min $^{-1}$.

Skin ground colour and flesh colour were measured with a Minolta Chroma meter (CR-300, Minolta, Ramsey, NJ, U.S.A.) tristimulus colour analyzer calibrated to a white porcelain reference plate. This colorimeter uses the CIELAB scale with colour space coordinates $L^{*}, a^{*}$, and $b^{*}$, hue angle $\left[H^{*}=\operatorname{arctangent}\left(b^{*} / a^{*}\right)\right]$ and Chroma $\left[C=\left(a^{* 2}+b^{* 2}\right)^{1 / 2}\right]$, which were determined around the equatorial region of the fruit (Brown and Walker, 1990; McGuire, 1992) considering three measurements per fruit. Acidity was determined using $2 \mathrm{~g}$ of sample diluted in $30 \mathrm{~mL}$ distilled water, and the acid was neutralized with $0.1 \mathrm{~N} \mathrm{NaOH}$ to $\mathrm{pH} 8.1$ using an automatic titration system (model 785 DMP Tinitro Metrohm Ltd., Switzerland); data was obtained as g malic acid $100 \mathrm{~mL}^{-1}$ (Witherspoon and Jackson, 1996). Finally, the soluble solids content was measured in ${ }^{\circ} \mathrm{Brix}$, calibrated as the percentage of sucrose at $20^{\circ} \mathrm{C}$, using an Ivymen Optic System (model DR101) hand-held refractometer.

In addition, some of the most important sensorial attributes were evaluated after the cold storage treatments as critical factors of consumer acceptance: visual appearance, fruit texture and flavor (Barret et al., 2010). The sensory tests were of descriptive type, being carried out in a consensual way by six experienced laboratory judges. Visual appearance was classified as good (appearance without external or internal defects), acceptable (appearance with minimal external or internal defects) or bad (appearance with significant external or internal defects). Fruit texture was also categorized as good (firm, crunchy and pleasant fruit texture), acceptable (fruit texture slightly soft but adequate) or bad (fruit too soft). Flavor - as a result of the mixture of sugars, acids, and volatile compounds (Baldwin et al., 2002) - was classified on a scale of 0 to 10 , similar to that used by Azodanlou et al. (2003); 0 was considered extremely bad and 10 extremely good. Finally, the presence of internal browning and pasty fruit (cloying fruits with an unpleasant texture) was also noted.

\section{Statistical analysis}

Data were analyzed using Infostat v. 15, and the differences between genotypes (varieties) and treatments (storage conditions) as well as genotype-treatment interactions were determined by analysis of variance (ANOVA) considering significant differences at $\mathrm{p}$-value $<0.05$.

Data were subjected to Tukey's multiple comparison test $(\mathrm{P}<0.05)$ to determine the differences within traits in each treatment (variety). In addition, the effect of the most significant treatments as well as all varieties evaluated were represented by principal component analysis (PCA) in order to show the phenotypic explanation variance in the $\mathrm{x}$ and $\mathrm{y}$ axes using each evaluated trait as variable.

\section{Results}

\section{Evaluation of fresh apricot fruits}

The descriptive statistics of the pomological traits for each variety at optimum eating ripeness time are summarized in Table 3. These results show wide variability in fruit quality between the apricot varieties assayed (Supplemental Table S1a).

The fruit weight ranged from $50 \mathrm{~g}$ for 'Deseo' to $90 \mathrm{~g}$ for 'Estrella', while average fruit firmness ranged from 30 to 50 N. As for skin colour, 'Deseo', 'Cebas 57', 'Estrella,' 'Mirlo anaranjado', 'Mirlo blanco', 'Rosa', 'Sublime' and 'Tardorange' reached an intense orange skin colour close to $80 \mathrm{H}^{\circ}$ while 'Búlida' and 'Currot' were characterized by lighter orange skin colour. No appreciable differences between skin colour and flesh colour were found.

In terms of soluble solids content, 'Deseo', 'Sublime' and 'Tardorange' showed the highest values, over $15^{\circ} \mathrm{Brix}$, while 'Rosa' had the lowest amount $\left(10^{\circ} \mathrm{Brix}\right)$; the rest of the varieties showed values between 12 and $15^{\circ}$ Brix. As for malic acid, 'Sublime' and 'Estrella' had the highest levels, both reaching $1.73 \mathrm{~g} 100 \mathrm{~mL}^{-1}$ of malic acid; 'Deseo', 'Cebas 57', 'Mirlo anaranjado', 'Murciana', 'Tardorange' and 'Valorange', on the other hand, showed low acidity levels $\left(1 \mathrm{~g} 100 \mathrm{~mL}^{-1}\right)$. In our assay, 'Tardorange' showed the highest sugar acid ratio (16.09) due to high soluble solids content and low acidity. 'Murciana' and 'Deseo' were second in the soluble solids-titratable acidity ratio ranking with values of 13.09 and 14.07 , respectively. In addition, 'Sublime' showed high levels of soluble solids (over $15^{\circ} \mathrm{Brix}$ ), but its soluble solids-titratable acidity ratio (9.07) was very low due to a high acidity level (Table 3).

\section{Evaluation of apricot fruits after different storage treatments}

According to ANOVA results, there were significant differences among genotypes and treatments, as well as differences for the genotype-treatment interaction for all evaluated traits (Supplemental Table S1a, b). In addition, most of the varieties showed significant differences for each evaluated trait after the different storage treatments (Supplemental Table S1c). However, the varieties 'Cebas 57', 'Búlida,' 'Currot', 'Mirlo anaranjado', 'Sublime' and 'Dorada' did not show significant differences in terms of soluble solids content, and 'Dorada' showed no significant differences in malic acid content as a result of the different storage treatments.

As for fruit weight loss, the best postharvest behavior was obtained for 'Deseo,' 'Dorada', 'Maravilla', 'Murciana' and 'Rosa' after 35 days at $1^{\circ} \mathrm{C}$ (T9), with weight loss values below $10 \%$, while other varieties obtained values over $10 \%$ or even 15\% (Figure 1, Supplemental Table S2). However, the 


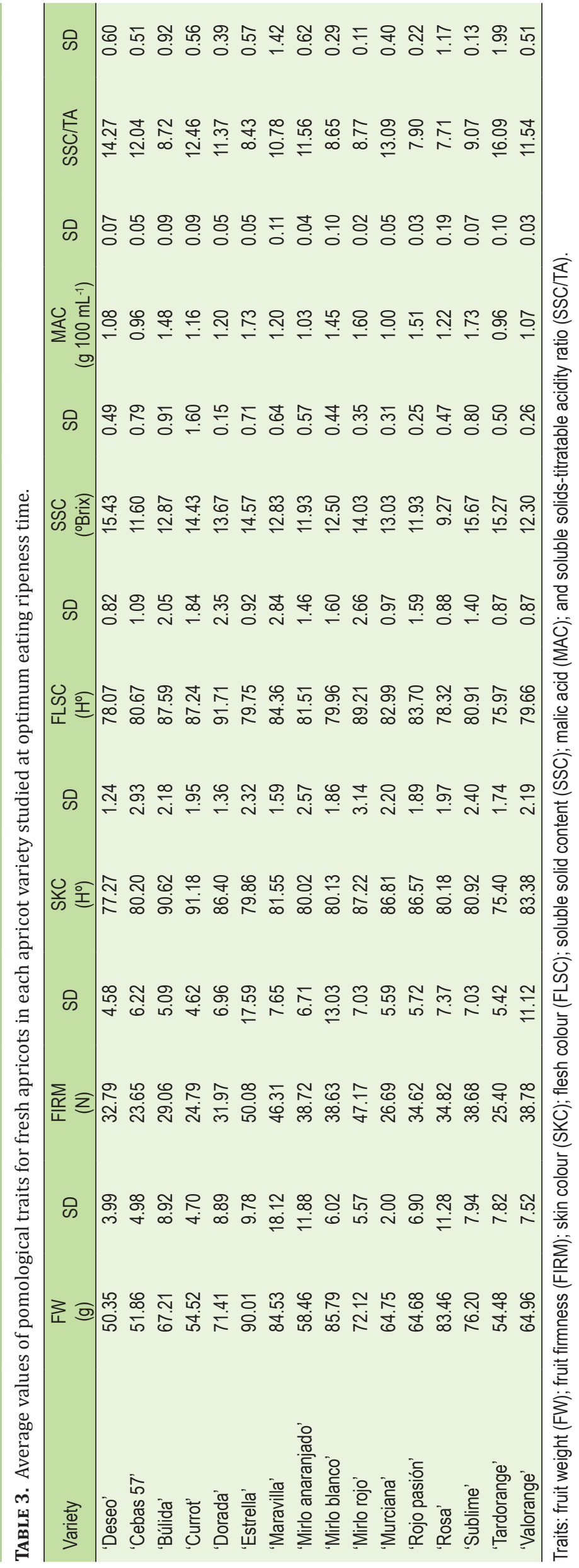


cold-storage period of most varieties could be extended up to 25 days (T6) (Table 4b).

Fruit firmness values at commercial maturity (T0) were higher than the values in fresh samples at optimum ripeness (Table 3; Supplemental Table S2). In order to better understand the fruit firmness evolution, we have summarized the fruit firmness results using fruits at harvest (T0, at commercial maturity) and after cold storage for 15, 25 and 35 days at $1^{\circ} \mathrm{C}$ and 2 days at $20^{\circ} \mathrm{C}(\mathrm{T} 4, \mathrm{~T} 7$ and $\mathrm{T} 10)$ (Figure 2). Figure 2 shows a considerable decrease in fruit firmness during the first 15 days between $\mathrm{T} 0$ and $\mathrm{T} 4$, although most varieties remained fruit firmness over optimum eating ripeness (15 N) for these storage periods. As for the cold treatments followed by 3 days at $20^{\circ} \mathrm{C}$, most firmness values were below $15 \mathrm{~N}$, especially after 35 days at $1^{\circ} \mathrm{C}$ (Supplemental Table S2). In general, all varieties maintained adequate fruit firmness after 15 days at $1^{\circ} \mathrm{C}(\mathrm{T} 3)$ or 25 days of cold storage (T6) (Table $4 \mathrm{a}, \mathrm{b})$, but they needed to be consumed immediately after cold storage. The varieties that maintained suitable firmness values for consumption ( $>15 \mathrm{~N}$ ) after longer cold storage periods were 'Maravilla', 'Murciana' and 'Rosa' (Table 4b), all of which reached 35 days at $1^{\circ} \mathrm{C}$ and 2 days at $20^{\circ} \mathrm{C}$ (T10).

According to the colour evolution among the varieties we evaluated (Figure 1), there was a general decrease in

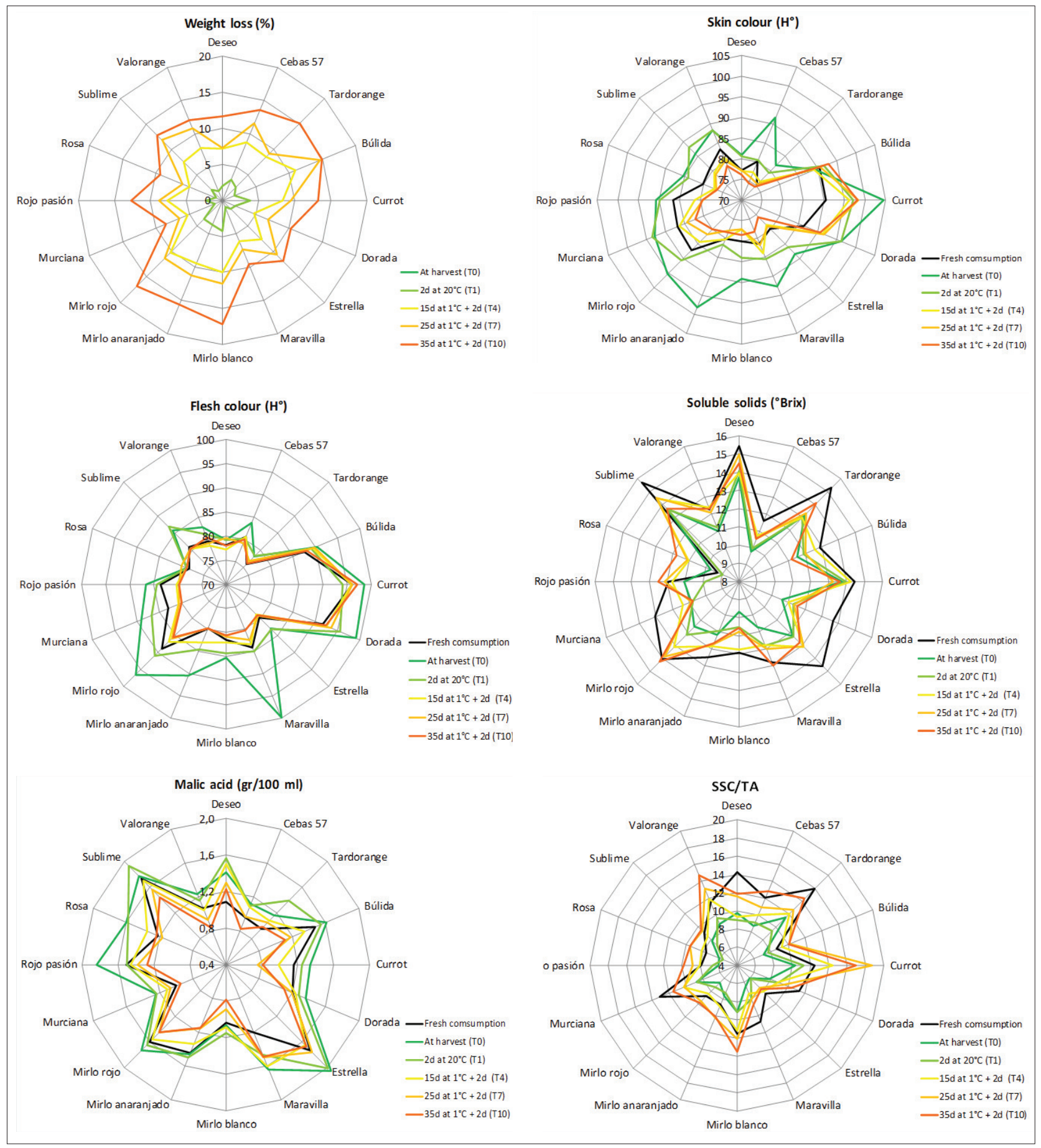

FIGURE 1. Fruit quality characterization of sixteen apricot varieties for different storage conditions: fresh consumption (optimum eating ripeness), harvest (commercial maturity, T0), 2 days of shelf-life at $20^{\circ} \mathrm{C}(\mathrm{T} 1), 15$ days at $1^{\circ} \mathrm{C}$ and 2 days at $20^{\circ} \mathrm{C}(\mathrm{T} 4), 25$ days at $1^{\circ} \mathrm{C}$ and 2 days at $20^{\circ} \mathrm{C}(\mathrm{T} 7)$ and 35 days at $1^{\circ} \mathrm{C}$ and 2 days at $20^{\circ} \mathrm{C}(\mathrm{T} 10)$. 
the angle $\left(\mathrm{H}^{\circ}\right)$ values, which corresponds to more orange skin shades when the treatments were longer. The fruit colour thus evolved towards orange shades closer to those of optimal ripening, despite cold storage period (Table 3; Supplemental Table S2), which is interesting given the fact that the fruits were collected slightly green. Most of the varieties evaluated reached skin colour values $\left(\mathrm{H}^{\circ}\right)$ below $80^{\circ}$ after storage treatments, indicating a colour change of around $10^{\circ}$ and $15^{\circ}$ between fruits at harvest (T0) and the end of the longest storage treatments. 'Mirlo anaranjado' and 'Cebas 57' showed the most remarkable results, with the colour changing around $20^{\circ}$ between harvest (T0) and the final treat- ments (Figure 1). The longer treatments produced a more orange skin colour despite the cold conditions.

The varieties with the most colour, 'Estrella' and 'Tardorange', reached a skin colour of around $70^{\circ}$, which indicated an intense red blush colour on the skin. The group with lighter skin colour included 'Búlida', 'Currot' and 'Dorada', all with $\mathrm{H}^{\circ}$ values above $90^{\circ}$ in the longest treatments (Figure 1). Flesh colour evolution was similar to that of the skin colour, although 'Maravilla' and 'Mirlo rojo' showed the greatest change (Figure 1).

As for soluble solids content, there was a general increase as the cold storage time increased, and certain values

TABLE 4a. Average values of pomological traits at the admissible shelf-life extension (admissible treatments for each variety according to the weight loss (WL) ${ }^{(1)}$ and firmness (FIRM) ${ }^{(2)}$ criteria: $\mathrm{WL}<10 \%$; FIRM $>15 \mathrm{~N}$ ) in the different apricot varieties evaluated (T3-T5).

\begin{tabular}{|c|c|c|c|c|c|c|c|c|}
\hline Treatment & Variety & $\begin{array}{l}W^{1} \\
(\%)\end{array}$ & $\begin{array}{l}\text { FIRM }^{2} \\
(\mathrm{~N})\end{array}$ & $\begin{array}{l}\text { SKC } \\
\left(H^{\circ}\right)\end{array}$ & $\begin{array}{c}\text { FLSC } \\
\left(\mathrm{H}^{\circ}\right)\end{array}$ & $\begin{array}{l}\text { SSC } \\
\left({ }^{\circ} \text { Brix }\right)\end{array}$ & $\begin{array}{c}\text { MAC } \\
\left.\text { (g } 100 \mathrm{~mL}^{-1}\right)\end{array}$ & SSC/TA \\
\hline \multirow[t]{16}{*}{ T3 } & 'Deseo' & 3.64 & 34.73 & 79.12 & 79.81 & 13.53 & 1.47 & 9.19 \\
\hline & 'Cebas 57' & 6.11 & 20.62 & 80.79 & 79.04 & 10.30 & 1.02 & 10.15 \\
\hline & 'Tardorange' & 5.30 & 24.99 & 79.59 & 79.01 & 13.13 & 1.14 & 11.59 \\
\hline & 'Búlida' & 6.17 & 29.78 & 91.42 & 91.38 & 11.27 & 1.39 & 8.09 \\
\hline & 'Currot' & 4.96 & 21.67 & 100.10 & 96.29 & 13.30 & 1.13 & 11.81 \\
\hline & 'Dorada' & 3.81 & 38.56 & 91.53 & 94.37 & 11.27 & 1.24 & 9.08 \\
\hline & 'Estrella' & 3.99 & 53.94 & 82.72 & 81.54 & 12.53 & 1.82 & 6.89 \\
\hline & 'Maravilla' & 3.73 & 71.21 & 91.93 & 91.92 & 11.17 & 1.52 & 7.33 \\
\hline & 'Mirlo blanco' & 5.92 & 28.29 & 80.64 & 81.47 & 9.47 & 1.01 & 9.42 \\
\hline & 'Mirlo anaranjado' & 5.73 & 33.84 & 85.20 & 81.90 & 11.07 & 1.31 & 8.47 \\
\hline & 'Mirlo rojo' & 7.42 & 43.73 & 89.19 & 92.43 & 12.27 & 1.68 & 7.31 \\
\hline & 'Murciana' & 4.00 & 44.46 & 92.10 & 85.91 & 10.73 & 1.31 & 8.21 \\
\hline & 'Rojo pasión' & 5.44 & 39.40 & 86.98 & 82.77 & 11.33 & 1.66 & 6.89 \\
\hline & 'Rosa' & 3.23 & 36.95 & 82.51 & 78.75 & 10.83 & 1.36 & 7.97 \\
\hline & 'Sublime' & 4.46 & 40.64 & 84.03 & 82.03 & 14.57 & 1.75 & 8.34 \\
\hline & 'Valorange' & 4.93 & 38.07 & 86.98 & 80.86 & 11.27 & 1.17 & 9.69 \\
\hline \multirow[t]{13}{*}{ T4 } & 'Deseo' & 7.15 & 18.06 & 77.03 & 77.15 & 13.97 & 1.50 & 9.30 \\
\hline & 'Tardorange' & 8.52 & 17.41 & 76.38 & 76.33 & 12.97 & 1.08 & 12.08 \\
\hline & 'Dorada' & 4.70 & 23.23 & 91.44 & 92.54 & 11.00 & 1.24 & 8.86 \\
\hline & 'Estrella' & 7.67 & 27.70 & 78.49 & 78.80 & 13.10 & 1.65 & 8.04 \\
\hline & 'Maravilla' & 6.13 & 38.02 & 83.92 & 83.47 & 11.80 & 1.61 & 7.34 \\
\hline & 'Mirlo blanco' & 9.97 & 18.08 & 77.08 & 82.03 & 11.73 & 1.09 & 11.15 \\
\hline & 'Mirlo anaranjado' & 9.48 & 19.85 & 80.32 & 83.01 & 11.87 & 1.34 & 8.90 \\
\hline & 'Mirlo rojo' & 10.25 & 19.04 & 84.28 & 86.87 & 13.10 & 1.56 & 8.40 \\
\hline & 'Murciana' & 5.30 & 22.86 & 86.34 & 80.73 & 11.37 & 1.11 & 10.28 \\
\hline & 'Rojo pasión' & 7.63 & 18.03 & 81.34 & 80.36 & 11.73 & 1.46 & 8.08 \\
\hline & 'Rosa' & 5.00 & 19.39 & 77.16 & 78.92 & 11.03 & 1.35 & 8.19 \\
\hline & 'Sublime' & 7.59 & 25.32 & 79.25 & 80.42 & 14.47 & 1.70 & 8.50 \\
\hline & 'Valorange' & 7.88 & 15.08 & 81.18 & 78.71 & 12.40 & 1.04 & 11.93 \\
\hline \multirow[t]{7}{*}{ T5 } & 'Currot' & 8.13 & 15.47 & 95.92 & 96.70 & 13.70 & 1.00 & 13.65 \\
\hline & 'Dorada' & 6.16 & 16.84 & 89.44 & 92.04 & 11.60 & 1.24 & 9.38 \\
\hline & 'Estrella' & 7.40 & 20.24 & 75.36 & 77.68 & 13.27 & 1.76 & 7.53 \\
\hline & 'Maravilla' & 6.45 & 31.66 & 80.50 & 80.85 & 12.90 & 1.54 & 8.36 \\
\hline & 'Mirlo blanco' & 9.11 & 17.52 & 76.49 & 81.17 & 10.67 & 1.02 & 10.45 \\
\hline & 'Murciana' & 6.81 & 15.30 & 81.13 & 78.58 & 12.27 & 1.03 & 11.96 \\
\hline & 'Sublime' & 8.32 & 16.64 & 74.68 & 77.89 & 14.87 & 1.57 & 9.51 \\
\hline
\end{tabular}

Traits: weight loss (WL); fruit firmness (FIRM); skin colour (SKC); flesh colour (FLSC); soluble solid content (SSC); malic acid (MAC) and soluble solids-titratable acidity ratio (SSC/TA).

Storage treatments: $\mathrm{T} 3\left(15\right.$ days at $\left.1^{\circ} \mathrm{C}\right), \mathrm{T} 4\left(15\right.$ days at $1{ }^{\circ} \mathrm{C}$ and 2 days at $\left.20^{\circ} \mathrm{C}\right)$ and $\mathrm{T} 5\left(15\right.$ days at $1^{\circ} \mathrm{C}$ and 3 days at $\left.20^{\circ} \mathrm{C}\right)$. 
even exceeded those of fresh fruit (Figure 1; Table 3). The differences in soluble solids were higher as the days of cold storage increased, especially in treatments with 2 or 3 days of storage at $20^{\circ} \mathrm{C}$. As expected, due to premature harvesting at the commercial maturity for postharvest treatments (Supplemental Table S2), most of the varieties presented soluble solids values lower than those accumulated in fresh apricots at optimum ripeness (Figure 1). It is noteworthy that varieties like 'Sublime', 'Estrella', 'Mirlo Rojo', 'Maravilla', 'Currot', 'Tardorange' and 'Deseo' obtained soluble solid values between 12 and $15^{\circ}$ Brix after storage treatments. Furthermore, all varieties reached soluble solids values above $10^{\circ}$ Brix, acceptable values for markets and consumers.

Acidity values showed small significant changes among cold storage periods. However, in the longer storage periods, acidity levels were actually lower compared to apricots at harvest (Figure 1). In general, we found a decrease of around

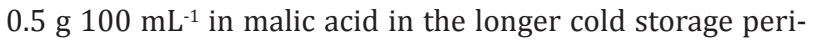
ods. Moreover, fruits subjected to longer cold storage periods achieved similar acidity levels to those of fruits picked at optimum ripeness; in the case of 'Búlida', 'Currot', 'Mirlo blanco', 'Mirlo rojo', 'Valorange', 'Sublime' and 'Rojo pasión', the acidity levels were even lower. Some varieties, such as 'Cebas 57', 'Valorange', 'Murciana', 'Mirlo Blanco' and 'Currot', reached acidity values below $1 \mathrm{~g} 100 \mathrm{~mL}^{-1}$ of malic acid after 35 days at $1^{\circ} \mathrm{C}$ and 2 days at $20^{\circ} \mathrm{C}(\mathrm{T} 10)$.

The soluble solids-titratable acidity ratio increased parallel to the cold storage time after harvesting. However, many varieties did not reach the soluble solids-malic acid ratio obtained for fresh consumption (Figure 1). 'Valorange', 'Rosa',

TABLE 4b. Average values of pomological traits at the admissible shelf-life extension (admissible treatments for each variety according to the weight loss (WL) ${ }^{(1)}$ and firmness (FIRM) ${ }^{(2)}$ criteria: $\mathrm{WL}<10 \%$; FIRM $>15 \mathrm{~N}$ ) in the different apricot varieties evaluated (T6-T11).

\begin{tabular}{|c|c|c|c|c|c|c|c|c|}
\hline Treatment & Variety & $\begin{array}{l}W L^{1} \\
(\%)\end{array}$ & $\begin{array}{l}\text { FIRM }^{2} \\
(\mathrm{~N})\end{array}$ & $\begin{array}{l}\text { SKC } \\
\left(H^{\circ}\right)\end{array}$ & $\begin{array}{c}\text { FLSC } \\
\left(\mathrm{H}^{\circ}\right)\end{array}$ & $\begin{array}{c}\text { SSC } \\
\text { ('Brix) }\end{array}$ & $\begin{array}{c}\text { MAC } \\
\left(\mathrm{g} 100 \mathrm{~mL}^{-1}\right)\end{array}$ & SSC/TA \\
\hline \multirow[t]{16}{*}{ T6 } & 'Deseo' & 7.10 & 25.09 & 77.92 & 78.68 & 14.80 & 1.42 & 10.49 \\
\hline & ‘Cebas 57' & 10.42 & 16.92 & 80.17 & 79.81 & 11.07 & 1.18 & 9.54 \\
\hline & 'Tardorange' & 7.67 & 20.65 & 78.53 & 77.48 & 13.00 & 1.03 & 12.72 \\
\hline & 'Búlida' & 9.39 & 21.33 & 91.14 & 90.77 & 11.43 & 1.31 & 8.71 \\
\hline & 'Currot' & 8.83 & 18.17 & 93.94 & 97.54 & 13.20 & 1.15 & 11.53 \\
\hline & 'Dorada' & 6.32 & 20.64 & 92.94 & 93.55 & 11.13 & 1.22 & 9.16 \\
\hline & 'Estrella' & 7.44 & 41.39 & 83.95 & 81.36 & 12.40 & 1.82 & 6.83 \\
\hline & 'Maravilla' & 5.16 & 47.29 & 85.85 & 87.74 & 12.37 & 1.50 & 8.23 \\
\hline & 'Mirlo blanco' & 10.00 & 17.03 & 80.31 & 80.35 & 10.80 & 1.01 & 10.69 \\
\hline & 'Mirlo anaranjado' & 9.62 & 23.80 & 82.62 & 81.78 & 11.57 & 1.27 & 9.24 \\
\hline & 'Mirlo rojo' & 9.92 & 35.04 & 88.48 & 88.64 & 12.07 & 1.62 & 7.46 \\
\hline & 'Murciana' & 4.82 & 32.23 & 87.85 & 83.11 & 10.73 & 1.02 & 10.56 \\
\hline & ‘Rojo pasión’ & 7.61 & 26.08 & 84.41 & 81.25 & 11.87 & 1.58 & 7.49 \\
\hline & 'Rosa' & 4.93 & 30.10 & 82.05 & 79.89 & 10.37 & 1.31 & 7.94 \\
\hline & 'Sublime' & 7.79 & 33.30 & 84.76 & 82.90 & 13.90 & 1.69 & 8.24 \\
\hline & 'Valorange' & 7.67 & 29.89 & 85.38 & 80.72 & 11.90 & 1.06 & 11.20 \\
\hline \multirow[t]{5}{*}{$\mathrm{T7}$} & 'Deseo' & 7.25 & 15.97 & 77.15 & 79.52 & 14.97 & 1.30 & 11.55 \\
\hline & 'Dorada' & 6.87 & 16.96 & 91.67 & 93.58 & 11.33 & 1.20 & 9.60 \\
\hline & 'Maravilla' & 7.33 & 35.23 & 81.84 & 82.52 & 12.03 & 1.50 & 8.03 \\
\hline & 'Murciana' & 6.49 & 20.55 & 84.26 & 80.56 & 10.90 & 1.07 & 10.18 \\
\hline & 'Rosa' & 5.98 & 15.09 & 76.68 & 80.07 & 11.10 & 1.17 & 9.49 \\
\hline \multirow[t]{2}{*}{ T8 } & 'Maravilla' & 10.13 & 21.78 & 78.06 & 79.20 & 13.20 & 1.53 & 8.69 \\
\hline & 'Murciana' & 8.21 & 16.65 & 82.22 & 79.76 & 11.23 & 1.02 & 10.98 \\
\hline \multirow[t]{5}{*}{ T9 } & 'Deseo' & 9.89 & 23.68 & 77.32 & 79.01 & 15.07 & 1.41 & 10.66 \\
\hline & 'Dorada' & 8.10 & 22.35 & 92.72 & 93.14 & 11.47 & 1.24 & 9.27 \\
\hline & 'Maravilla' & 7.52 & 25.61 & 82.26 & 84.46 & 12.73 & 1.53 & 8.36 \\
\hline & 'Murciana' & 5.75 & 28.26 & 86.54 & 82.59 & 10.93 & 1.05 & 10.47 \\
\hline & 'Rosa' & 6.23 & 21.12 & 81.49 & 79.70 & 10.50 & 1.25 & 8.41 \\
\hline \multirow[t]{3}{*}{ T10 } & 'Maravilla' & 9.53 & 23.19 & 78.26 & 80.30 & 13.00 & 1.49 & 8.74 \\
\hline & 'Murciana' & 8.51 & 16.91 & 82.10 & 79.97 & 10.77 & 0.94 & 11.49 \\
\hline & 'Rosa' & 9.33 & 16.52 & 76.51 & 78.94 & 11.77 & 1.24 & 9.51 \\
\hline T11 & 'Murciana' & 8.49 & 14.85 & 80.38 & 80.29 & 11.40 & 0.91 & 12.61 \\
\hline
\end{tabular}

Traits: weight loss (WL); fruit firmness (FIRM); skin colour (SKC); flesh colour (FLSC); soluble solid content (SSC); malic acid (MAC) and soluble solids-titratable acidity ratio (SSC/TA).

Storage treatments: $\mathrm{T} 6\left(25\right.$ days at $\left.1^{\circ} \mathrm{C}\right), T 7\left(25\right.$ days at $1^{\circ} \mathrm{C}$ and 2 days at $\left.20^{\circ} \mathrm{C}\right), \mathrm{T} 8\left(25\right.$ days at $1^{\circ} \mathrm{C}$ and 3 days at $\left.20^{\circ} \mathrm{C}\right), \mathrm{Tg}\left(35\right.$ days at $\left.1{ }^{\circ} \mathrm{C}\right)$, $\mathrm{T} 10\left(35\right.$ days at $1^{\circ} \mathrm{C}$ and 2 days at $\left.20^{\circ} \mathrm{C}\right)$ and $\mathrm{T} 11\left(35\right.$ days at $1^{\circ} \mathrm{C}$ and 3 days at $\left.20^{\circ} \mathrm{C}\right)$. 


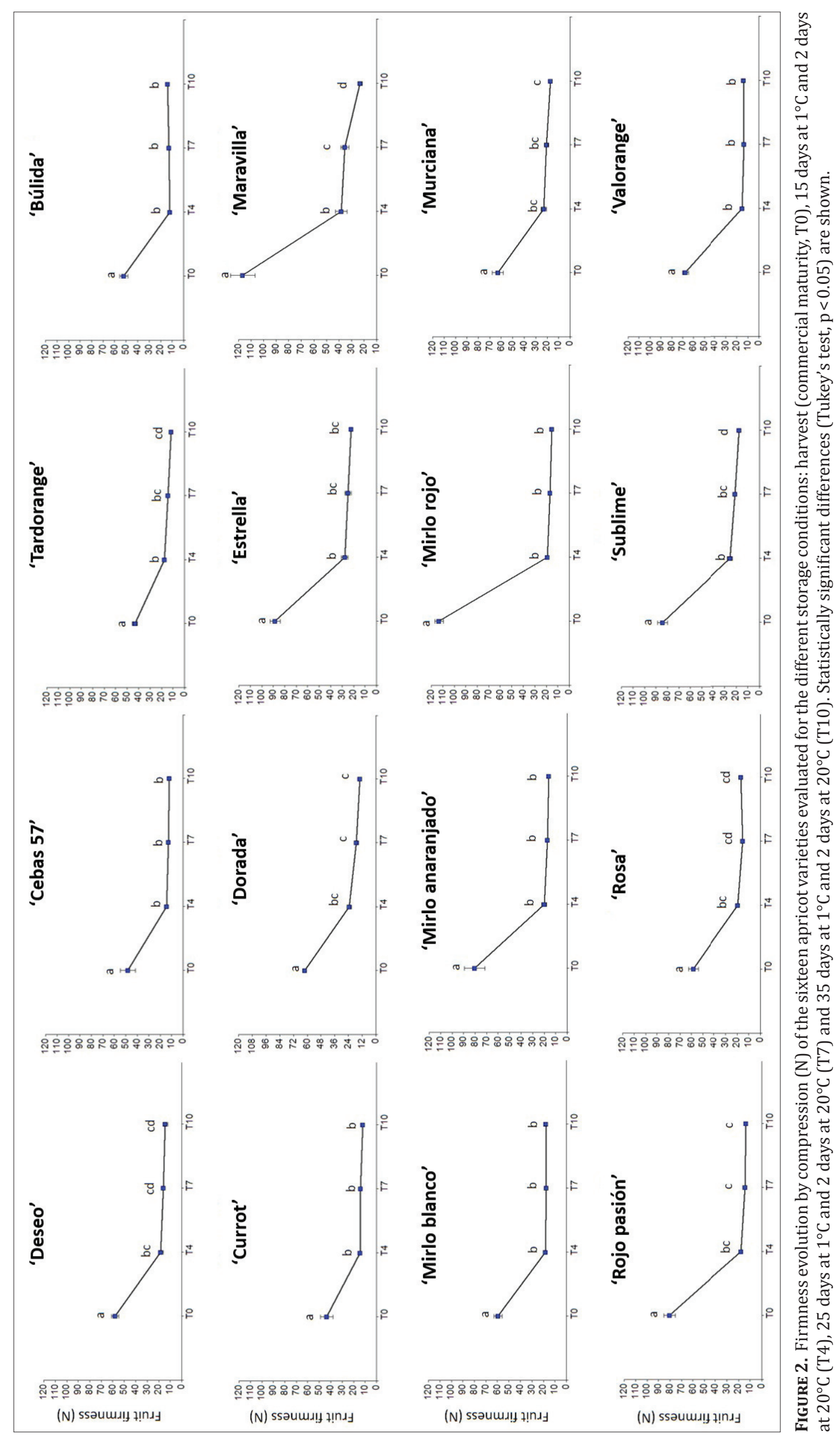




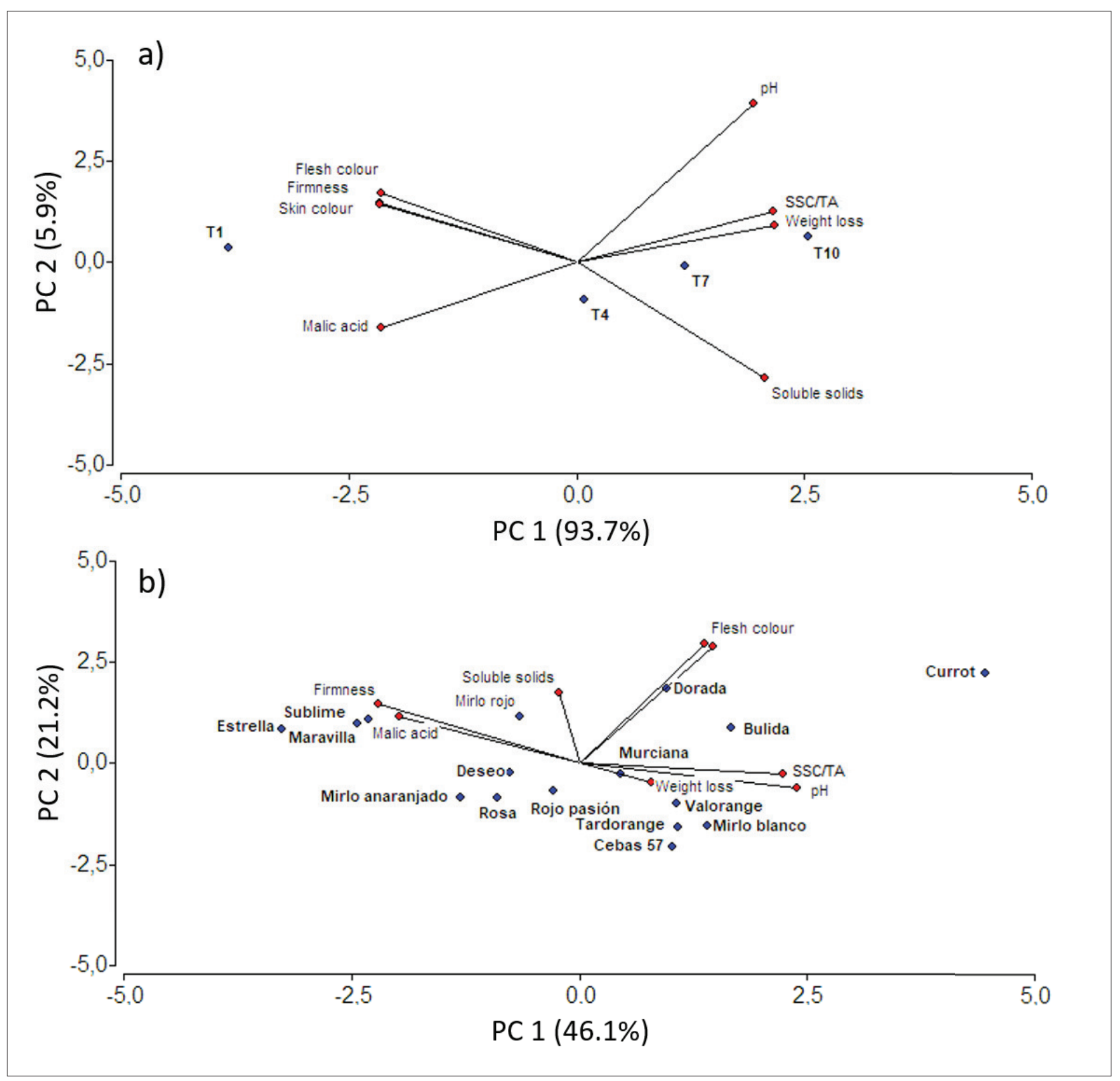

FigURE 3. Principal component analysis (PCA) for fruit quality traits. a) PCA considering treatment as factor $\left(2\right.$ days at $20^{\circ} \mathrm{C}$ (T1); 15 days at $1{ }^{\circ} \mathrm{C}$ and 2 days at $20^{\circ} \mathrm{C}$ (T4); 25 days at $1^{\circ} \mathrm{C}$ and 2 days at $20^{\circ} \mathrm{C}$ (T7) and 35 days at $1{ }^{\circ} \mathrm{C}$ and 2 days at $20^{\circ} \mathrm{C}$ (T10). b) PCA considering genotype (varieties) as factor.

'Mirlo blanco' and 'Currot', on the other hand, did show a higher SSC/TA ratio than fresh apricots during extended cold treatments. Overall, considering treatment as factor, PCA showed a phenotypic explanation variance (PEV) among traits in the x-axis of $93.7 \%$ (Figure 3a). On the other hand, considering genotype as factor the PEV in the $\mathrm{x}$-axis was $46.1 \%$ (Figure $3 b$ ). In addition, varieties such as 'Maravilla', 'Sublime' and 'Estrella' were all grouped together, mainly because they shared high firmness and acidity, as did 'Cebas 57', 'Valorange', 'Tardorange' and 'Mirlo blanco', mostly due to their weight loss and a good sugar acid balance. Other varieties like 'Dorada', 'Búlida' and 'Currot' were especially influenced by their light orange skin colour, while 'Currot' stood out as the most differentiated variety (Figure $3 b$ ).

We also determined certain sensorial attributes, such as visual appearance (including the internal and external fruit state), texture and flavor. In general, the visual appearance and fruit texture of stored fruits were good or acceptable and evolved similarly, except in the last cold storage peri- ods, in which some varieties showed bad fruit texture, which was sometimes related to pasty fruits (cloying fruits of unpleasant texture) or internal browning. As for flavor, 'Mirlo anaranjado' (T3) and 'Sublime' (T7), with a maximum grade of 7.5, were the most highly acceptable varieties, followed by 'Deseo' (T1), 'Estrella' (T5) and 'Maravilla' (T7) with a grade of 7.

In summary, if we consider the criteria of weight loss $(<10 \%)$ and fruit firmness $(>15 \mathrm{~N})$ as shown in Table $4 \mathrm{a}, \mathrm{b}$, all T6 $\left(25\right.$ days at $\left.1^{\circ} \mathrm{C}\right)$ varieties meet the criteria, but we have to bear in mind that they must be consumed immediately after cold storage. Moreover, 'Deseo', 'Dorada', 'Maravilla', 'Murciana' and 'Rosa' are able to withstand T7 (25 days at $1^{\circ} \mathrm{C}$ and 2 days at $20^{\circ} \mathrm{C}$ ) and T9 $\left(25\right.$ days at $\left.1^{\circ} \mathrm{C}\right)$, while 'Maravilla', 'Murciana' and 'Rosa' withstand T10 (35 days at $1^{\circ} \mathrm{C}$ and 2 days at $20^{\circ} \mathrm{C}$ ). In terms of sensorial attributes after cold storage, 'Maravilla' (7) and 'Deseo' (6.5) obtained the highest qualifications. 


\section{Discussion}

\section{Evaluation of fresh apricot fruits}

The evaluation of 16 apricot varieties showed a remarkable variability in skin colour, flesh colour, soluble solids content and malic acid determinant traits from the point of view of consumer acceptance. 'Deseo', 'Estrella' and 'Tardorange' highlighted for their intense orange skin colour which is usually related to higher carotenoid levels resulting in more attractive fruits (Ruiz et al., 2005), while the traditional varieties 'Búlida' and 'Currot' tended to have a lighter orange skin colour (Ruiz et al., 2005).

As for SSC, 'Sublime' and 'Rosa' were the contrasting varieties showing presumably the highest and lowest sugar content respectively, as well as in the case of MAC 'Sublime' and 'Estrella' were the most acidic varieties, contrary to 'Cebas 57' and 'Tardorange'. According to Moreau-Rio (2006), consumer appreciation is partially influenced by the SSC-TA ratio, so a good balance between soluble solids and malic acid is recommended. Although a high soluble solids-titratable acidity ratio is usually interpreted as adequate for consumers, low ratios can be balanced by high soluble solids levels as in the case of 'Sublime', resulting in acceptable and even exceptional taste, depending on the consumer's preferences. In conclusion, to define an adequate soluble solids-titratable acidity ratio is not an easy task because it depends of consumer acceptance. In this context, Crisosto et al. (2004) in stone fruits as plum reported that the interaction between soluble solids and titratable acidity is especially relevant from the consumer point of view when the varieties reach SSC $<12 \%$ and $\mathrm{TA}>0.9 \%$.

\section{Evaluation of apricot fruits after different storage treatments}

As expected, the wide range of varieties from CEBAS-CSIC research center showed a significant difference between genotypes and treatments as well as most of the evaluated traits showed a different postharvest behavior which are indicating the wide germplasm variability used to obtain these varieties (Egea et al., 2010a, b; Salazar et al., 2015). The evaluated traits after harvest, including weight loss, fruit softening, fruit colour, soluble solids content, malic acid as well as soluble solids-titratable acidity ratio are considered some of the most common and useful traits from the fruit quality and postharvest point of view as reported in other works such as Ghasemnezhad et al. (2010), Manganaris and Crisosto (2020), or Salazar et al. (2013).

Fruit weight loss is undoubtedly an important agronomic parameter since fruit dehydration is directly linked to fruit weight loss. In our assay 'Deseo,', 'Dorada,' 'Maravilla', 'Murciana' and 'Rosa' reached weight loss values below $10 \%$ after 35 days at $1^{\circ} \mathrm{C}$ while the rest exceeded this value. Previous studies in apricot reflect the fact that weight loss in storage is genotype-dependent: the 'Precoce de Tyrinthe' variety showed weight loss values of around $4 \%$ after a 7 -day cold treatment and 2 days at $20^{\circ} \mathrm{C}$ (Agar et al., 2006), while the 'Bebeco' variety showed weight loss values above $10 \%$ after 16 days at $4{ }^{\circ} \mathrm{C}$ (Panou et al., 2018). In order to minimize fruit weight losses, the combined application of $\mathrm{CaCl}_{2}$ and $\mathrm{KMnO}_{4}$ could result in weight loss lower than $5 \%$ during a 10 -day storage period at $28-30^{\circ} \mathrm{C}$, as reported by Ishaq et al. (2009). Additionally, recent studies, such as that of Ezzat et al. (2017), have reported that treatments with methyl jasmonate and salicylic acid reduce apricot weight loss and could therefore be an alternative for extending apricot shelf-life in future trials.
Fruit softening is considered to be the greatest limiting factor in the lifetime of fruits; in apricot, softening is usually related to increasing pectin solubilization (Stanley et al., 2013). Fruits characterized by a firmness below $15 \mathrm{~N}$ are considered too soft for consumption (Crisosto, 1999). In the present assay most of the varieties maintained adequate firmness values after 15 or 25 days of cold storage. 'Maravilla', 'Murciana' and 'Rosa' were the varieties that best endured the loss of fruit firmness (>15 N) for longer cold storage. Previous studies have found different values for different varieties: Agar et al. (2006), for instance, showed an average firmness value of around $10 \mathrm{~N}$ for 'Precoce de Tyrinthe' after 7 days of cold storage and 2 days at $20^{\circ} \mathrm{C}$. Infante et al. (2008b) also obtained firmness values of around 15-25 $\mathrm{N}$ after cold treatments of $0,14,28$ and 42 days for different maturity states in 'Palsteyn', while Panou et al. (2018) obtained a fruit firmness of around $10 \mathrm{~N}$ for 'Bebeco' after 16 days at $4^{\circ} \mathrm{C}$.

In order to slow down fruit softening and extend the shelf-life period of apricot varieties, it could be of interest to use chemical products like putrescine (Martínez-Romero et al., 2002); different concentrations of $\mathrm{CaCl}_{2}, \mathrm{NaHCO}_{3}$ and salicylic acid and packing materials (Moradinezhad and Jahani, 2016); or products that regulate ethylene emission like 1-methylcyclopropene (1-MCP) and aminoethoxyvinylglycine (AVG). For instance, after applying 1-MCP and AVG to different apricot varieties, Valdés et al. (2009) found a fruit firmness of around 10 and $15 \mathrm{~N}$ after 30 days of cold storage and 1 day at $20^{\circ} \mathrm{C}$. More recently, Fan et al. (2018b) reported that treatment with 1-MCP is effective for delaying fruit softening in apricot by delaying pectin degradation, while exogenous ethylene treatments could improve consumer acceptability by producing higher soluble solids accumulation, organic acid degradation and colour change and by accelerating the ripening process.

As we have already stated, skin and flesh colour are major traits for the perception and consumer acceptance. In this assay there was a fruit colour evolution from pale yellow to intense orange which was reflected in a general decrease of the angle $\mathrm{H}^{\circ}$ as the storage period was longer. This is indicating, that although the fruits were harvested slightly green, they showed values that approached the fruits harvested at optimum ripeness. 'Mirlo anaranjado' and 'Cebas 57' were the varieties that experienced major skin colour variation between the beginning and the last storage treatment, while 'Estrella' and 'Tardorange' as expected, were the varieties reaching the most intense orange skin colour as at optimum ripeness consumption. Agar et al. (2006) obtained colour values for the $\mathrm{H}^{\circ}$ angle below $80^{\circ}$ from the second day at $20^{\circ} \mathrm{C}$ after 7 days of prior cooling, while Infante et al. (2008b) obtained colour values below $70^{\circ}$ for 'Palsteyn', but only in the samples harvested at more advanced ripening states. Panou et al. (2018) showed that the $a^{*}$ colour parameter increased after 16 days of cold storage in 'Bebeco', which implied a decrease in $\mathrm{H}^{\circ}$ towards a more orange skin colour. In all of these studies, there was a similar trend to that found in the present work.

As for soluble solids content, in the present work a general increase was observed, however in a previous work in apricot, Aubert et al. (2010) did not find major changes in soluble solids content among different storage treatments and maturity stages. Similarly, in other studies such as those performed by Agar et al. (2006) and Panou et al. (2018), researchers did not observe a clear trend in the level of soluble solids content during the cold storage period, but rather found more evident differences if the fruits were harvested 
at different stages of maturity (Infante et al., 2008b). This fact could be due to the different genetic background of the varieties used in this trial as well as to a premature maturity state at harvest, which has allowed a greater fruit evolution. However, the acidity levels showed almost no variation, except for the most prolonged cold treatments as compared to the freshly harvested fruits. Similar results were found in previous works (Agar et al., 2006; Infante et al., 2008b; Aubert et al., 2010).

According to sensorial attributes such as visual appearance, texture and flavor, these traits are considered as some of the most important parameters that influence the eating quality of apricots (Byrne, 2002; Infante et al., 2008b; Llácer, 2009) and therefore consumer acceptance. Overall, in our assay the majority of the varieties showed an acceptable sensorial attribute except for longer cold storage periods with the fungi appearance. Manganaris and Crisosto (2020) assert that apricots are highly susceptible to gel breakdown (translucent, gelatinous mass) or internal breakdown (flesh browning), which could occur due to a fungal disease caused by Monilinia fructicola or Botrytis cinerea.

In summary, our results show significant differences among varieties in terms of postharvest behavior and the effects of shelf-life extension. As a result, we are able to classify the varieties into groups characterized by low (cold storage $\leq 15$ days), medium (cold storage up to 25 days) or high postharvest aptitude (cold storage $\geq 35$ days), according to the point at which the fruits maintain acceptable quality characteristics for the consumer. Therefore, if we consider the criteria of weight loss $(<10 \%)$ and fruit firmness ( $>15 \mathrm{~N})$ 'Deseo', 'Dorada', 'Maravilla', 'Murciana' and 'Rosa' could be considered as high postharvest aptitude apricot varieties since at least they reached 35 days of cold storage.

Finally, especially in the more perishable varieties, we should not rule out the combined use of cold storage and chemical treatments on fruits picked at optimum ripeness/ optimum eating ripeness in order to extend the shelf-life of the product, keeping in mind that the fruit must reach consumers meeting minimum standards of quality and in optimal conditions.

\section{Conclusion}

While low temperatures and high humidity slowed the weight loss of the apricot fruits, the effect was insufficient given that most varieties showed a weight loss values of above $5 \%$ after fifteen days of cold treatment. The effect of cold at $1{ }^{\circ} \mathrm{C}$ and relative humidity of $90 \%$ was more effective in slowing fruit firmness evolution, and most treatments showed fruit firmness above $15 \mathrm{~N}$, which is considered suitable for consumption. Slight colour changes were also observed, and in most cases, the stored fruits showed less colour than fresh fruits. In some cases, the soluble solids content and acidity levels showed a similar evolution to that observed in fresh fruit, especially in the longest cold storage periods. We observed significant differences among varieties, which shows that postharvest behavior is genotype-dependent. It should be also noted that many of the varieties described have exceptional organoleptic qualities, despite having a shorter shelf-life, such as 'Mirlo anaranjado', 'Sublime' and 'Estrella'. It would be interesting to study the shelf-life extension of these varieties after cold storage applying different treatments, including methyl jasmonate, calcium chloride $\left(\mathrm{CaCl}_{2}\right)$, salicylic acid, chlorine dioxide $\left(\mathrm{ClO}_{2}\right)$, ozone or ethylene inhibitors such as 1-MCP and AVG. On the other hand, varieties such as 'Deseo' and 'Maravilla' showed both a longer shelf-life - up to 35 days - and acceptable sensorial qualities. These varietal differences have important implications for apricot breeding and production. Our results allowed us to identify the most suitable apricot varieties for prolonged conservation periods in our breeding program: 'Deseo', 'Dorada', 'Maravilla', 'Murciana' and 'Rosa'. These varieties are thus ideal for long-distance export. This knowledge could be a key element to consider for their potential commercial production and also for use as genitors in apricot breeding programs for this purpose.

\section{Acknowledgments}

This study has been supported by the "Apricot Breeding" (AGL2017-86627-R) project of the Spanish Ministry of Economy and Competiveness and the projects "Breeding stone fruit species assisted by molecular tools" (19879/ GERM/15), the Regional Saavedra Fajardo Subprogram (20397/SF/17) of the "Fundación Séneca" of the Region of Murcia and "Juan de la Cierva Incorporación" project $\mathrm{N}^{\circ}$ IJC2018-036623-I.

\section{References}

Agar, T., Paydas, S., Ozkaya, O., Buyukalaca, O., and Ekinci, F. (2006). Effect of harvest dates and forced air cooling on post-harvest quality of apricot cv. 'Precoce de Tyrinthe'. Acta Hortic. 701, 577-580. https://doi.org/10.17660/ActaHortic.2006.701.101.

Ali, S., Masud, T., Abbasi, K.S., Mahmood, T., and Hussain, A. (2015). Apricot: nutritional potentials and health benefits - A review. Ann. Food Sci. Technol. 16, 175-189.

Aubert, C., and Chanforan, C. (2007). Postharvest changes in physicochemical properties and volatile constituents of apricot (Prunus armeniaca L.). Characterization of 28 cultivars. J. Agric. Food Chem. 55, 3074-3082. https://doi.org/10.1021/jf063476w.

Aubert, C., Bony, P., Chalot, G., and Hero, V. (2010). Changes in physicochemical characteristics and volatile compounds of apricot (Prunus armeniaca L. cv. Bergeron) during storage and post-harvest maturation. Food Chem. 119, 1386-1398. https://doi.org/10.1016/j. foodchem.2009.09.018.

Azodanlou, R., Darbellay, C., Luisier, J.L., Villettaz, J.C., and Amadò, R. (2003). Development of a model for quality assessment of tomatoes and apricots. LWT - Food Sci. Technol. 36, 223-233. https://doi. org/10.1016/S0023-6438(02)00204-9.

Baldwin, E.A. (2002). Fruit flavor: Volatile metabolism and consumer perceptions. In Fruit Quality and its Biological Basis, M. Knee, ed. (Sheffield, U.K.: Sheffield Academic Press), p. 89-106.

Barrett, D.M., Beaulieu, J.C., and Shewfelt, R. (2010). Color, flavor, texture, and nutritional quality of fresh-cut fruits and vegetables: Desirable levels, instrumental and sensory measurement, and the effects of processing. Crit. Rev. Food Sci. Nutr. 50, 369-389. https:// doi.org/10.1080/10408391003626322.

Brown, G.S., and Walker, T.D. (1990). Indicators of maturity in apricots using biplot multivariate analysis. J. Sci. Food Agric. 53, 321-331. https://doi.org/10.1002/jsfa.2740530305.

Byrne, D.H. (2002). Peach breeding trends: A worldwide perspective. Acta Hortic. 592, 49-59. https://doi.org/10.17660/ ActaHortic.2002.592.5.

Contador, L., Días, M., Millanao, M., Hernández, P., Shinya, C., Sáenz, R., et al. (2016). A proposal for determining the flesh softening of peach and nectarine in postharvest through simplified targeted modeling. Sci. Hortic. 19, 47-52. https://doi.org/10.1016/j. scienta.2016.06.015.

Crisosto, C., and Kader, A. (2009). Figs Postharvest Quality Maintenance Guidelines. https://ucanr.edu/sites/kac/files/123820.pdf. 
Crisosto, C.H., and Kader, A. (2016). Apricot: The commercial storage of fruits, vegetables, and florist and nursery stocks. Agric. Handb. 66, 195-197.

Crisosto, C.H., Garner, D., Crisosto, G.M., and Bowerman, E. (2004). Increasing 'Blackamber' plum (Prunus salicina L.) consumer acceptance. Postharvest Biol. Technol. 34, 237-244. https://doi. org/10.1016/j.postharvbio.2004.06.003.

Dong, L., Lurie, S., and Zhou, H.W. (2002). Effect of 1-methylcyclopropene on ripening of 'Canino' apricots and 'Royal Zee' plums. Postharvest Biol. Technol. 24, 135-145. https://doi.org/10.1016/ S0925-5214(01)00130-2.

Egea, J., Dicenta, F., Burgos, L., Martínez-Gómez, P., Rubio, M., Campoy, J., Ortega, E., Patiño, J.L., Nortes, L., Molina, A., and Ruiz, D. (2010a). New apricot cultivars from CEBAS-CSIC (Murcia, Spain) breeding programme. Acta Hortic. 862, 113-118. https://doi.org/10.17660/ ActaHortic.2010.862.17.

Egea, J., Rubio, M., Campoy, J.A., Dicenta, F., Ortega, E., Nortes, M.D., Martínez-Gómez, P., Molina, A., Molina Jr., A., and Ruiz, D. (2010b). 'Mirlo Blanco', 'Mirlo Anaranjado', and 'Mirlo Rojo': Three new very early-season apricots for the fresh market. HortScience 45, 18931894. https://doi.org/10.21273/HORTSCI.45.12.1893.

Ezzat, A., Ammar, A., Szabó, Z., Nyéki, J., and Holb, I.J. (2017). Postharvest treatments with methyl jasmonate and salicylic acid for maintaining physico-chemical characteristics and sensory quality properties of Apricot fruit during cold storage and shelflife. Polish J. Food Nutr. Sci. 67, 159-166. https://doi.org/10.1515/ pjfns-2016-0013.

Fan, X., Xi, Y., Zhao, H., Liu, B., Cao, J., and Jiang, W. (2018a). Improving fresh apricot (Prunus armeniaca L.) quality and antioxidant capacity by storage at near freezing temperature. Sci. Hortic. 231, 1-10. https://doi.org/10.1016/j.scienta.2017.12.015.

Fan, X., Shu, C., Zhao, K., Wang, X., Cao, J., and Jiang, W. (2018b). Regulation of apricot ripening and softening process during shelf-life by post-storage treatments of exogenous ethylene and 1-methylcyclopropene. Sci. Hortic. 232, 63-70. https://doi. org/10.1016/j.scienta.2017.12.061.

Fan, X., Argenta, L., and Mattheis, J.P. (2000). Inhibition of ethylene action by 1-methylcyclopropene prolongs storage life of apricots. Postharvest Biol. Technol. 20, 135-142. https://doi.org/10.1016/ S0925-5214(00)00121-6.

Fratianni, F., Ombra, M.N., d'Acierno, A., Cipriano, L., and Nazzaro, F. (2018). Apricots: Biochemistry and functional properties. Curr. Opin. Food Sci. 19, 23-29. https://doi.org/10.1016/j.cofs.2017.12.006.

Ghasemnezhad, M., Shiri, M.A., and Sanavi, M. (2010). Effect of chitosan coatings on some quality indices of apricot (Prunus armeniaca L.) during cold storage. Caspian J. Env. Sci. 8(1), 25-33.

Gurrieri, F., Audergon, J.M., Albagnac, G., and Reich, M. (2001). Soluble sugars and carboxylic acids in ripe apricot fruit as parameters for distinguishing different cultivars. Euphytica 117, 183-189. https:// doi.org/10.1023/A:1026595528044.

Infante, R., Kraemer, F., Luchsinger, L., Meneses, C., and Aros, D. (2006). Sensorial postharvest quality evolution in apricot (Prunus armeniaca L.) cvs. 'Palsteyn' and 'Grandir'. Acta Hortic. 717, 321-326. https://doi.org/10.17660/ActaHortic.2006.717.64.

Infante, R., Martínez-Gómez, P., and Predieri, S. (2008a). Quality oriented fruit breeding: Peach [Prunus persica (L.) Batsch]. J. Food Agric. Environm. 6, 342-356.

Infante, R., Meneses, C., and Defilippi, B.G. (2008b). Effect of harvest maturity stage on the sensory quality of 'Palsteyn' apricot (Prunus armeniaca L.) after cold storage. J. Hortic. Sci. Biotechnol. 83, 828832. https://doi.org/10.1080/14620316.2008.11512468.
Ishaq, S., Rathore, H.A., Masud, T., and Ali, S. (2009). Influence of post-harvest calcium chloride application, ethylene absorbent and modified atmosphere on quality characteristics and shelf-life of apricot (Prunus armeniaca L.) fruit during storage. Pakistan J. Nutr. 8, 861-865. https://doi.org/10.3923/pjn.2009.861.865.

Llácer, G. (2009). Fruit breeding in Spain. Acta Hortic. 814, 43-56. https://doi.org/10.17660/ActaHortic.2009.814.1.

Lurie, S., and Weksler, A. (2005). Effects of 1-methylcyclopropene on stone fruits. Acta Hortic. 682, 85-90. https://doi.org/10.17660/ ActaHortic.2005.682.4.

Manganaris, G., and Crisosto, C. (2020). Stone fruits: Peaches, nectarines, plums, apricots. In Controlled and Modified Atmospheres for Fresh and Fresh-Cut Produce, M.I. Gil, and M. Beaudry, eds. (London, U.K.: Academic Press), p. 311-322. https://doi. org/10.1016/B978-0-12-804599-2.00017-X.

Manolopoulou, H., and Mallidis, C. (1999). Storage and processing of apricots. Acta Hortic. 488, 567-576. https://doi.org/10.17660/ ActaHortic.1999.488.93.

Martínez-Romero, D., Serrano, M., Carbonell, A., Burgos, L., Riquelme, F., and Valero, D. (2002). Effects of postharvest putrescine treatment on extending shelf-life and reducing mechanical damage in apricot. J. Food Sci. 67, 1706-1712. https://doi. org/10.1111/j.1365-2621.2002.tb08710.x.

McGuire, R.G. (1992). Reporting of objective color measurements. HortScience 27, 1254-1255.

Melgarejo, P., Calin-Sánchez, A., Carbonell-Barrachina, A.A., MartínezNicolas, J.J., Legua, P., Martínez, R., and Hernández, F. (2014). Antioxidant activity, volatile composition and sensory profile of four new very-early apricots (Prunus armeniaca L.). J. Sci. Food Agric. 94, 85-94. https://doi.org/10.1002/jsfa.6201.

Moradinezhad, F., and Jahani, M. (2016). Quality improvement and shelf-life extension of fresh apricot fruit (Prunus armeniaca cv. Shahroudi) using postharvest chemical treatments and packaging during cold storage. Intl. J. Hortic. Sci. Technol. 3, 9-18. https://doi. org/10.22059/IJHST.2016.58156.

Moreau-Rio, M.A. (2006). Perception and consumption of apricots in France. Acta Hortic. 701, 31-38. https://doi.org/10.17660/ ActaHortic.2006.701.1.

Panou, A.A., Karabagias, I.K., and Riganakos, K.A. (2018). The effect of different gaseous ozone treatments on physicochemical characteristics and shelf-life of apricots stored under refrigeration. J. Food Process. Preserv. 42(21). https://doi.org/10.1111/ jfpp. 13614

Reid, M.S. (1992). Maturation and maturity indices. In Peaches, Plums and Nectarines: Growing and Handling for Fresh Market, J.H. La Rue, and R.S. Johnson, eds. (Oakland, CA, U.S.A.: University of California, Dept. of Agriculture and Natural Resources), Publ. No. 3331, 21-28.

Ruiz, D., and Egea, J. (2008). Phenotypic diversity and relationships of fruit quality traits in apricot (Prunus armeniaca L.) germplasm. Euphytica 163, 143-158. https://doi.org/10.1007/s10681-0079640-y.

Ruiz, D., Egea, J., Tomas-Barberan, F.A., and Gil, M.I. (2005) Carotenoids from new apricot (Prunus armeniaca L.) varieties and their relationship with flesh and skin color. J. Agric. Food Chem. 53(16), 6368-6374. https://doi.org/10.1021/jf0480703.

Salazar, J.A., Ruiz, D., Egea, J., and Martínez-Gómez, P. (2013). Transmission of fruit quality traits in apricot (Prunus armeniaca L.) and analysis of linked quantitative trait loci (QTLs) using Simple Sequence Repeat (SSR) markers. Plant Mol. Biol. Rep. 31, 1506-1517. https://doi.org/10.1007/s11105-013-0625-9. 
Salazar, J.A., Rubio, M., Ruiz, D., Tartarini, S., Martínez-Gómez, P., and Dondini, L. (2015). SNP development for genetic diversity analysis in apricot. Tree Genet. Genomes 11, 15. https://doi.org/10.1007/ s11295-015-0845-2.

Salazar, J., Jorquera, C., Campos-Vargas, R., Jorgensen, C., Zapata, P., and Infante, R. (2019). Effect of the application timing of 1-MCP on postharvest traits and sensory quality of a yellow-fleshed kiwifruit. Sci. Hortic. 244, 82-87. https://doi.org/10.1016/j. scienta.2018.09.028.

Sims, E.T., and Comin, D. (1963). Evaluation of objective maturity indices for Halehaven peaches. Proc. Am. Soc. Hortic. Sci. 82, 125130.

Souty, M., Audergon, J.M., and Duprat, F. (1991). Physical and biochemical criteria for apricot varieties characterization. Acta Hortic. 293, 95-110. https://doi.org/10.17660/ActaHortic.1991.293.9.

Stanley, J., Prakash, R., Marshall, R., and Schröder, R. (2013). Effect of harvest maturity and cold storage on correlations between fruit properties during ripening of apricot (Prunus armeniaca). Postharvest Biol. Technol. 82, 39-50. https://doi.org/10.1016/j. postharvbio.2013.02.020.

Valdés, H., Pizarro, M., Campos-Vargas, R., Infante, R., and Defilippi, B. (2009). Effect of ethylene inhibitors on quality attributes of Apricot cv. Modesto and Patterson during storage. Chilean J. Agric. Res. 69, 134-144. https://doi.org/10.4067/S0718-58392009000200002.

Witherspoon, J.M., and Jackson, J.F. (1996). Analysis of fresh and dried apricot. In Modern Methods of Plant Analysis. Fruit Analysis, H.F. Linskens, and J.F. Jackson, eds. (Berlin, Heidelberg: SpringerVerlag), p. 111-131. https://doi.org/10.1007/978-3-642-796609_7.

Xi, W., Zheng, H., Zhang, Q., and Li, W. (2016). Profiling taste and aroma compound metabolism during apricot fruit development and ripening. Int. J. Molec. Sci. 17(7), 998. https://doi.org/10.3390/ ijms17070998.

Received: Sep. 15, 2020

Accepted: May 18, 2021

Address of authors:

Juan A. Salazar*, Pedro Martínez-Gómez and David Ruiz

Departamento de Mejora Vegetal, CEBAS-CSIC, P.O. Box 164,

E-30100 Espinardo, Murcia, Spain

* Corresponding author; E-mail: jasalazar@cebas.csic.es

SUPPLEMENTAL INFORMATION - TABLES S1-S3

For Supplemental Information see www.ishs.org./eJHS 
